Volume 1, No. 1, April 2021

\title{
DIALEKTIKA POLITIK HUKUM ISLAM DALAM PEMBANGUNAN SISTEM HUKUM NASIONAL
}

\author{
Ainun Najib \\ Program Studi Hukum Keluarga Islam, Fakultas Syariah dan Ekonomi Islam \\ Universitas Ibrahimy Situbondo \\ Email: adjie245@gmail.com
}

\begin{abstract}
Abstrak
Keberadaan hukum Islam telah berlaku di Indonesia sejak zaman kerajaankerajaan Nusantara hingga saat ini, bahkan hukum Islam sudah menjadi sumber hukum utama bagi mayoritas penduduk Indonesia. Namun secara konstitusional Indonesia tidak menyatakan diri sebagai negara Islam, meskipun mayoritas peduduknya beragama Islam. Indonesia menganut bukan negara agama, namun juga bukan negara sekuler, tetapi secara filosofis adalah negara religius meskipun secara bentuk kelembagaan adalah sekuler. Sehingga norma-norma hukum agama, termasuk norma hukum Islam, dapat menjadi salah satu sumber materiil dalam pembentukan regulasi hukum atau peraturan perundang-undangan. Fenomena terintegrasinya beberapa prinsip, nilai dan ketentuan formal hukum Islam ke dalam sistem hukum nasional tentu tidak muncul secara tiba-tiba. Namun proses ini terjadi melalui pergulatan yang panjang, serta di dalamnya sarat dengan kepentingan politik. Dari sekian rezim yang berkuasa di Indonesia, semuanya memiliki karakteristik yang berbeda dalam memberlakukan hukum Islam yang tumbuh dan berkembang di masyarakat. Peran politik hukum terhadap pembangunan hukum nasional di Indonesia tidak bisa lepas dari konteks sejarah. Sepanjang sejarah Negara Republik Indonesia telah terjadi perubahan-perubahan politik secara bergantian (bedasarkan periodisasi sistem politik) antara politik yang demokratis dan politik otoriter. Sejalan dengan perubahan-perubahan politik itu, karakter produk hukum juga akan berubah. Terjadinya perubahan itu karena hukum merupakan produk politik, maka karakter produk hukum berubah jika politik yang melahirkannya berubah.
\end{abstract}

Kata Kunci : Pembaharuan Hukum, Efektifitas, Berkeadilan

\begin{abstract}
The existence of Islamic law has been in effect in Indonesia since the days of the archipelago kingdoms until now, even Islamic law has become the main source of law for the majority of the Indonesian population. However, constitutionally, Indonesia does not declare itself as an Islamic state, even though the majority of the population is Muslim. Indonesia adheres to not a religious state, but also not a
\end{abstract}


secular state, but philosophically it is a religious state even though its institutional form is secular. So that the norms of religious law, including the norms of Islamic law, can be one of the material sources in the formation of legal regulations or statutory regulations. The phenomenon of the integration of several principles, values and formal provisions of Islamic law into the national legal system certainly did not appear suddenly. However, this process occurred through a long struggle, and it was filled with political interests. Of the many regimes in power in Indonesia, all of them have different characteristics in enforcing Islamic law that grows and develops in society. The role of legal politics in the development of national law in Indonesia cannot be separated from the historical context. Throughout the history of the Republic of Indonesia, there have been alternating political changes (based on the periodization of the political system) between democratic politics and authoritarian politics. In line with these political changes, the character of legal products will also change. This change occurs because the law is a political product, so the character of the legal product changes if the politics that gave birth to it change.

Keywords : Legal Reform, Effectiveness, Fairness

\section{PENDAHULUAN}

\section{A. Latar Belakang}

Politik dan hukum dapat diibaratkan sebagai dua sisi mata uang logam, keduanya tidak dapat di pisahkan. Pengibaratan ini memberi makna bahwa hubungan antara politik dan hukum sangatlah erat. Bila kita membahas atau membicarakan penyelenggaan negara atau pemerintahan, baik di tingkat pusat maupun daerah, maka politik dan hukum selalu mendapatkan tempat yang utama. Bahkan hubungan hukum dan poitik melebihi keeratan hubungan pada bidangbidang lainnya. Hukum selalu menjadi sarana dari politik untuk mempengaruhi, membangun dan mengembangkan bidang-bidang yang lain. Dalam hal inilah berlaku tesis bahwa "hukum adalah keputusan politik" (lawa is a political decision). ${ }^{1}$

Secara definisi, politik hukum memiliki keragaman yang cukup variatif. Meskipun demikian, terdapat persamaan substantif antar berbagai pengertian tentang politik hukum, yaitu kebijakan hukum atau legal policy yang akan atau telah dilaksanakan secara nasional oleh pemerintah. Kebijakan hukum ini

\footnotetext{
${ }^{1}$ Bintan Regen Saragih, Politik Hukum, (Bandung: CV. Utomo, 2006), hlm. 5.
} 
meliputi: pembangunan hukum, pelaksanaan ketentuan hukum, termasuk penegasan atas fungsi para aparat penegak hukum. ${ }^{2}$ Dengan pengertian tersebut maka pembahasan politik hukum adaah untuk mencapai tujuan negara dengan sistem hukum.

Dalam dimensi filosofis-teoritis, politik hukum merupakan parameter nilai bagi implementasi pembangunan dan pembinaan hukum di lapangan. Sedangkan politik hukum dalam dimensi normatif-operasional merupakan cerminan kehendak-kehendak sosial penguasa terhadap konstruksi masyarakat yang diinginkan. Dimensi filosofis-teoritis dalam negara Indonesia berupa Pancasila sebagai cita-cita hukum, dan dimensi normatif-operasional dalam bentuk Indonesia sebagai negara hukum. ${ }^{3}$ Politik hukum bertugas meneliti perubahan mana saja yang perlu dilakukan terhadap hukum yang sudah ada, agar dapat memenuhi kebutuhan-kebutuhan baru di dalam kehiduan masyarakkat, dan meneruskannya pada arah perkembangan tertib hukum.

Secara garis besar hukum berfungsi sebagai kontrol sosial (social control, dispute settlement dan social engineering atau innoation). Sedangkan fungsi politik meliputi pemeliharaan sistem dan adaptasi (socialization dan recruitment), konversi (rule making, rule application, rule adjudication dan agregation) dan fungsi kapabilitas(regulatif extarctif, distributif dan responsif).

Indonesia adalah merupakan suatu negara yang secara konstitusional tidak menyatakan diri sebagai negara Islam, meskipun mayoritas peduduknya menganut agama Islam. Keberadaan hukum Islam telah berlaku di Indonesia sejak zaman kerajaan-kerajaan sampai sekarang, bahkan hukum Islam sudah menjadi sumber hukum utama di Indonesia. Sebagai negara bangsa, Indonesia memiliki karakteristik tersendiri dalam sistem negaranya. Dimana negara menganut bukan negara agama, namun juga bukan negara sekuler, tetapi secara filosofis adalah negara religius meskipun secara bentuk kelembagaan adalah sekuler. Sehingga norma-norma hukum agama, termasuk norma hukum Islam, dapat menjadi salah satu sumber materiil dalam pembentukan regulasi hukum atau peraturan perundang-undangan.

${ }^{2}$ Moh. Mahfud MD, Politik Hukum di Idonesia, Cet. 6 (Jakarta: Raja Grafindo Persada, 2014), hlm.9.

${ }^{3}$ Sirajuddin M., Legislasi Hukum Islam di Indonesia, (Yogyakarta: Pustaka Pelajar,2008), hlm. vii. 
Selain sistem hukum Islam, di Indonesia berlaku juga sistem hukum yang lain. Sistem hukum yang dimaksud adalah sistem hukum adat dan hukum Barat. Ketiga sistem hukum tersebut mulai berlaku di Indonesia pada waktu yang berlainan. Hukum adat telah lama ada dan berlaku di kepulauan Nusantara, walaupun sebagai sebuah sistem hukum baru dikenal pada permulaan abad ke20. ${ }^{4}$ Hukum Barat mulai diperkenalkan di Indonesia oleh pemerintah VOC setelah menerima kekuasaan untuk berdagang dan menguasai kepulauan Nusantara dari pemerintah Belanda pada tahun 1602. Mula-mula hukum Barat hanya diberlakukan terhadap orang-orang Belanda dan Eropa saja, tetapi kemudian dengan berbagai peraturan dan upaya, dinyatakan berlaku bagi orang Asia dan dianggap berlaku juga bagi orang Indonesia yang menundukkkan dirinya pada hukum Barat dengan sukarela atau karena melakukan suatu perbuatan hukum tertentu di bidang keuangan, perdagangan, dan ekonomi pada umumnya. Ketiga sistem hukum itu diakui oleh peraturan perundang-undangan, tumbuh dalam masyarakat, dikembangkan oleh ilmu pengetahuan dan praktik peradilan. ${ }^{5}$

Hukum Islam sejak kedatanggannya ke Nusantara hingga saat ini merupakan hukum yang hidup (living law), tidak hanya pada tataran simbol, melainkan juga pada tataran praktis. Hal tersebut bukan semata-mata sebagai sebuah tanda bahwa mayoritaspemeluk agama di Indonesia adalah agama Islam, melainkan dalam realitas alaminya di beberapa daerah hukum Islam sudah menjadi tradisi (adat) yang terkadang dianggap sakral. ${ }^{6}$ Secara sosiologis dan kultural, hukum Islam merupakan hukum yang mengurat dan mengakar dalam kehidupan masyarakat. Hal ini disebabkan fleksibilitas dan elastisitas yang dimiliki hukum Islam. Artinya, meskipun pada kekuatan otonom yang terdapat dalam ketetapan Tuhan, namun dalam realitasnya mampu melakukan upaya transformative-adaptif.

Ketika berbicara tentang hukum Islam, maka akan memunculkan konotasi dengan kekuasaan dan kewenangan Pengadilan Agama, padahal, sesungguhnya ketika berbicara hukum Islam, ia tidak hanya berbicara tentang pengadilan, tetapi

\footnotetext{
${ }^{4}$ Mustofa dan Abdul Wahid, Hukum Islam Kontemporer, (Jakarta: Sinar Grafika, 2009), hlm. 115.

${ }^{5}$ Ibid.

${ }^{6}$ Sirajuddin M., Legislasi Hukum Islam di Indonesia, hlm. 14.
} 
berbicara seluruh aspek hidup dan kehidupan umat. Hal ini ditandai dengan ragam definisi atau terminologi terhadap hukum Islam itu sendiri. Hal ini terjadi sesuai dengan perkembangan zaman, perluasan wilayah Islam serta hubungannya dengan budaya dan umat lain. Sirajuddin M mengutip pendapat MacDonald yang menggambarkan hukum Islam sebagai the science of all things, human and devine. Hukum Islam adalah pengetahuan terhadap segala hal baik yang bersifat manusiawi mauun ketuhanan. ${ }^{7}$ Oleh karena posisinya yang dapat mengikat seluruh aspek kehidupan, maka hukum Islam tidak hanya mengatur pemeluknya saja, melainkan juga pada seluruh aspek kehidupan masyarakat lain secara luas.

Sejauh ini dikotomi antara hukum Islam dan hukum positif lebih dikarenakan adanya pemahaman yang demikian sempit terhadap hukum Islam itu sendiri. Hukum Islam dipandang sebagai hukum Tuhan yang absolut, suci dan dianggap tidak mampu mengadopsi realitas masyarakat di mana hukum Islam itu hidup. Hal inilah yang menjadi salah satu faktor sulitnya pertumbuhan dan perkembangan hukum Islam dalam pembangunan sistem hukum nasional.

Studi politik hukum Islam di Indonesia sama artinya memerbincangkan kepentingan mayoritas masyarakat Indonesia. Kedudukan hukum Islam dalam tatanan hukum nasional di Indonesia telah diakui sebagai bahan baku bagi pembentukan hokum nasional, bersama-sama denan sistem hukum yang lain, yaitu hukum Barat adan hukum adat. Pengakuan terhadap eksistensi hukum Islam sebagai salah satu pilar dalam pembentukan hukum nasional dapat menjadi peluang bagi umat Islam untuk memberikan konstribusi paling besar dalam konfigurasi hukum nasional Indonesia. Oleh karena itu, umat Islam secara internal peru mempersiapkan langkah secara lebih sistematis dan terencana dalam menawarkan konsep hukum Islam yang relevan dengan konteks keIndonesia-an, agar rumusan hukum Islam tersebut bisa diterima dan dapat dijadikan bahan dalam membangun hukum nasional.

Fenomena mulai terintegrasinya beberapa prinsip, nilai dan ketentuan formal hukum Islam ke dalam sistem hukum nasional ini tentu saja tidak muncul

\footnotetext{
${ }^{7}$ Ibid. hlm. 10.
} 
secara tiba-tiba. Namun proses ini terjadi melalui pergulatan yang panjang, serta di dalamnya sarat dengan kepentingan politik. Dari sekian rezim yang berkuasa di Indonesia, semuanya memiliki karakteristik yang berbeda dalam memberlakukan hukum Islam yang tumbuh dan berkembang di masyarakat. Peran politik hukum terhadap pembangunan hukum nasional di Indonesia tidak bisa lepas dari konteks sejarah. Sepanjang sejarah Negara Republik Indonesia telah terjadi perubahan-perubahan politik secara bergantian (bedasarkan periodisasi sistem politik) antara politik yang demokratis dan politik otoriter. Sejalan dengan perubahan-perubahan politik itu, karakter produk hukum juga akan berubah. Terjadinya perubahan itu karena hukum merupakan produk politik, maka karakter produk hukum berubah jika politik yang melahirkannya berubah.

Menunjukkan eksistensi hukum Islam yang telah mengakar kuat dalam kehidupan berbangsa dan bernegara, diperlukan proses dialektis secara keilmuan antara pemikir muslim dan pemerintah selaku pemangku kebijakan untuk dapatnya hukum Islam dijadikan sebagai salah satu sumber hukum yang dapat dijadikan sebagai dasar pembentukan hukum dalam sistem pembangunan hukum nasional. Di sinilah letak urgensi pentingnya melihat persoalan posisi dan eksistensi hukum Islam dalam bangunan hukum nasional dari perspektif politik hukum, baik di masa lalu, masa kini dan juga di masa yang akan datang.

\section{B. Rumusan Masalah}

Berdasarkan uraian latar belakang di atas, maka studi ini akan memfokuskan pada rumusan masalah terhadap konsep pembangunan sistem hukum nasional yang menjadi dasar pijakan politik hukum di Indonesia, bagamana dialektika politik hukum Islam dalam pembangunan sistem hukum nasional, serta bagaimana eksistensi hukum Islam dalam konfigurasi politik hukum Indonesia dimasa yang akan datang.

\section{Metode Penelitian}

Studi ini merupakan kajian hokum normatif dengan menggunakan pendekatan hostoris (historical approach), yaitu pendekatan yang digunakan untuk mengetahui nilai-nilai sejarah yang menjadi latar belakang serta yang berpengaruh terhadap nilai-nilai yang terkandung dalam sebuah peraturan 
perundang-undangan. ${ }^{8}$ Pendekatan ini bertujuan untuk menelaah tentang sejarah dalam pokok pembahasan penelitian hukum. Pendekatan ini dilakukan dalam kerangka untuk memahami filosofi aturan hukum dari waktu ke waktu, serta memahami perubahan dan perkembangan filosofi yang melandasi aturan hukum tersebut. Cara pendekatan ini dilakukan dengan menelaah latar belakang dan perkembangan pengaturan mengenai isu hukum yang terjadi dari saturezim pemerintahan ke rezim pemerintahan yang lain.

\section{PEMBAHASAN}

\section{Konsep Pembangunan Sistem Hukum Nasional}

Setelah adanya amandemen UUD 1945 yang didalamnya memberikan konstruksi baru pada sistem ketatanegaraan Indonesia, hal tersebut berimplikasipada penyusunan program pembangunan hukum, dan pembangunan pada umumnya, yang sebelumnya biasa ditetapkan dalam GBHN (Garis-garis Besar Haluan Negara) oleh MPR. ${ }^{9}$ GBHN adalah haluan negara tentang penyelenggaraan negara dalam garis-garis besar sebagai pernyataan kehendak rakyat secara menyeluruh dan terpadu. GBHN ditetapkan oleh MPR untuk jangka waktu 5 tahun. ${ }^{10}$

Perjalanan pembangunan di Indonesia dipandu dokumen GBHN yang diberlakukan dengan Ketetapan Majelis Permusyawaratan Rakyat (Tap MPR). Sejak 1 April 1969 hingga 21 Mei 1998, tidak kurang dari enam Tap MPR tentang GBHN. Enam Tap MPR tersebut, yaitu: (i) Tap MPR No. IV/MPR/1973; (ii) Tap MPR No. II/MPR/ 1978; (iii) Tap MPR No. IV/MPR/1983; (iv) Tap MPR No. II/MPR/1988; (v) Tap MPR No. II/MPR/1993; dan terakhir (vi) Tap MPR No. II/MPR/1998. Untuk konteks pemerintah daerah (provinsi dan kabupaten/kota),dokumen GBHN ini diterjemahkan ke dalam dokumen Pola Dasar Pembangunan Daerah (Poldasbangda).

Dalam kurun waktu 32 tahun pemerintahan Orde Baru di bawah kepemimpinan nasional yang sama (Presiden Soeharto), MPR telah berhasil menetapkan sebanyak enam GBHN (GBHN 1973, 1978, 1983, 1988, 1993 dan 1998). Artinya setiap sidang lima tahunan, MPR menjalankan tugas rutin menetapkan GBHN

\footnotetext{
${ }^{8}$ S. Nasution, Metode Research (Penelitian Ilmiah), Cetakan ke-4, (Jakarta: PT. Bumi Aksara, 2011), hlm. 16 ${ }^{9}$ Mokhammad Najih, Pengantar Hukum Indonesia, cet.3 (Malang: Setara Press, 2013), hal. 83-85

${ }^{10}$ Refli Harun, Kajian Politik Hukum terhadap Perencanaan Pembangunan Nasional Semesta Berencana Guna Meningkatkan Daya Bangsa, makalah disampaikan di Semarang tanggal, 28 Juli 2016, hlm 6.
} 
yang akan diamanatkan kepada Presiden. Rutinitas yang dilakukan oleh MPR ini seakan tidak melihat faktor riil kebutuhan dan perkembangan hukum masyarakat.

Pembangunan hukum pada masa itu tidak begitu mendapatkan perhatian, justeru program tersebut inklud dalam bagian dari Bidang Politik, serta tidak ada tindakan evaluatif dari MPR atas capaian program pembangunan hukum atas GBHN sebelumnya. Penekanan pada paradigma pembangunan untuk mewujudkan pembangunan manusia Indonesia seutuhnya, menempatkan pembangunan hukum sebagai penunjang atau pelengkap pembangunan ekonomi. Sehingga GBHN berikutnya bahkan cenderung sebagai bentuk repetisi dari GBHN yang sudah ada.

Sudah seharusnya guna mewujudkan Pembangunan Jangka Panjang tersebut, MPR merumuskan sasaran pembangunan bidang hukum adalah terbentuk dan berfungsinya sistem hukum nasional yang mantap dengan memperhatikan kemajemukan tatanan hukum yang berlaku yang mampu menjamin kepastian, ketertiban, penegakan, dan perlindungan hukum serta mengamankan dan mendukung pembangunan nasional yang didukung oleh aparatur hukum, sarana dan prasarana serta masyarakat yang sadar dan taat hukum. Untuk dapat membangun hukum secara tepat dalam kedudukannya sebagai bagian sistem pembangunan nasional tersebut, hukum harus bersifat otonom. ${ }^{11}$

Oleh karena itu untuk pembagian bidang pembangunan dalam GBHN 1993, pembangunan hukum dikeluarkan dari pembangunan bidang politik dan ditempatkan sebagai bidang tersendiri (otonom). Amanat pembangunan hukum di sini mencakup 3 (tiga) komponen, yakni Materi Hukum, Aparatur Hukum, dan Sarana dan Prasarana Hukum. GBHN 1993 secara formal telah membuka jalan tampilnya tatanan hukum yang bukan sebagai subsistem tatanan politik, tatanan ekonomi dan sebagainya melainkan sebagai tatanan dari sistem nasional. Langkah ini dimaksudkan untuk melakukan peralihan dari hukum yang represif menuju ke hukum yang otonom dengan menekankan pada ciri rule of law dan rule by law. ${ }^{12}$

\footnotetext{
11 Lili Rasyidi menegaskan dalam hubungan dengan pembangunan hukum hal ini tidak mudah diselesaikan karena sampai saat ini masih berkembang aneka pandangan tentang ruang lingkup hukum. Sebab dari semua ini karena diferensiasi ilmu pengetahuan yang berlangsung sejak abad ke 17 dan menajam pada abad ke-19.

${ }^{12}$ Arief Sidharta, Hukum dan Logika, (Bandung: Alumni, 2006), hlm. 90.
}

\section{HUKMY|Jurnal Hukum}


Sekalipun pembangunan bidang hukum mendapatkan tempat tersendiri, namun pada era ini hukum hanya dipandang sebagai alat kekuasaan represif dari pengemban kekuasaan politik Orde Baru yang memiliki kewenangan diskresi tanpa batas, sebagaimana hal itu dicirikan oleh Nonet-Selznick: "Kekuasaan politik memiliki akses langsung pada institusi hukum sehingga tata hukum praktis identik dengan negara dan hukum disubordinasi pada "raison d'etat" 13

Memasuki era reformasi dan terjadinya perubahan (amandemen) UUD 1945 maka terjadi perubahan garis politik hukum dalam konsep pembangunan nasional, dengan dikeluarkannya UU No. 17 Tahun 2007 tentang RPJPN, maka Garis-garis Besar Haluan Negara (GBHN) tidak lagi dikenal sebagaimana pernah dipraktekkan sebelumnya. Sehingga, dibutuhkan suatu panduan yang menjadi penggerak berbagai agenda pembangunan di setiap tingkatan dalam konteks saling terkoordinasi satu sama lain. Undang-Undang RPJPN bermula saat pemerintah mengajukan draft RUU tentang Rencana Pembangunan Jangka Panjang Nasional (RPJPN) 2005-2025 kepada DPR untuk dibahas lebih lanjut. RUU ini adalah tindaklanjut atas Surat Presiden No. R01/PU/III/2005 tertanggal 18 Maret 2005 yang telah disampaikan kepada DPR. Usaha tersebut merupakan konsekuensi atas keluarnya Undang-Undang No. 25 tahun 2004 tentang Sistem perencanaan Pembangunan Nasional, khususnya sebagaimana ditegaskan dalam Pasal 13 ayat (1), yang mengamanatkan adanya suatu dokumen negara mengenai perencanaan jangka panjang. ${ }^{14}$

RPJPN dapat menjadi panduan untuk menentukan arah pembangunan selama jangka waktu yang panjang, yaitu selama 20 tahun, meskipun pengesahannya adalah pada 5 Februari 2007, nomenklatur tahunnya yaitu sejak 2005, sudah terlampaui selama 2 tahun. Panduan ini sekaligus memuat berbagai visi dan misi yang akan dijabarkan lebih lanjut dalam berbagai program yang ada hingga di tingkat agenda kerja di lapangan. ${ }^{15}$ Undang-Undang RPJPN tidak saja merupakan perintah legalistik tentang perencanaan, tetapi juga mempunyai dimensi historis dan tantangan

\footnotetext{
${ }^{13}$ Philippe Nonet and Philip Selznick, Law and Transition: Towards Responsive Law, Harper \& Row, (New York, 1978), hlm.33. Legal institution are directly accessible to political; law is identified with the state and subordinate to raison d'etat.

${ }^{14}$ Prayudi, RJPN Tahun 2005-2025 Sebagai Landasan Pembanguan Politik Memperkuat Demokrasi, (Jurnal Konstitusi, Volume 4, Nomor 3, September 2007), hlm. 95

${ }^{15}$ Lihat tentang kewenangan ini dalam Pasal 7 Undang-Undang RPJPN.
} 
tersendiri di tengah perubahan sosial politik yang terjadi di era reformasi. ${ }^{16}$

Dalam Undang-Undang RPJPN Tahun 2005-2025 masing-masing kondisi umum dan tantangan yang dihadapi, diformulasikan dalam tujuan untuk mewujudkan kondisi terbaik yang ingin dicapai. Tujuan tersebut memuat beberapa sasaran pokok dalam dua puluh tahun mendatang

Acuan Perencanaan Pembangunan yang menggantikan GBHN adalah dokumen Rencana Pembanganan Jangka Panjang Nasional (RPJPN) 2005-2025 yang ditetapkan dengan UU No. 17/2007. RPJP Nasional merupakan penjabaran dari tujuan dibentuknya pemerintahan Negara Indonesia yang tercantum dalam Pembukaan Undang-Undang Dasar Negara Republik Indonesia Tahun 1945, dalam bentuk visi, misi, dan arah pembangunan Nasional. ${ }^{17}$ Skala waktu RPJP adalah 20 tahun, yang kemudian dijabarkan dalam RPJM (Rencana Pembangunan Jangka Menengah).

Namun demikian, upaya perwujudan masyarakat adil dan makmur melalui berbagai program perencanaan tersebut masih menghadapi hambatan dan kendala yang tidak mudah diselesaikan. Berbagai kendala dan tantangan datang silih berganti, mulai dari merosotnya kewibawaan Negara, melemahnya sendi-sendi perkonomian bangsa, dan toleransi dan krisis kepribadian bangsa. ${ }^{18}$ Berbagai pengalaman, baik dari faktor internal maupun eksternal seperti arus globalisasi dunia telah membuat Bangsa Indonesia harus lebih banyak belajar untuk menyusun tahapan perencanaan pembangunan yang lebih baik pada tahun-tahun mendatang.

\section{Dialektika Politik Hukum Islam dalam Pembangunan Sistem Hukum Nasional}

Persentuhan Islam dan politik di Indonesia mulai tampak ke permukaan pada awal kemerdekaan Indonesia, tepatnya ketika bangsa ini meraih kemerdekaannya tahun 1945. Seperti yang tercatat dalam sejarah, pada masa itu terjadi perdebatan yang sangat sengit terkait dua hal, yaitu mengenai dasar Negara dan dimasukkan atau tidaknya tujuh kata pada sila pertama pancasila (peristiwa ini kemudian disebut dengan piagam Jakarta). Karena itu, menurut Menteri Agama Era Orde Baru, Jenderal Alamsyah Ratu Perwiranegara, Pancasila adalah hadiah terbesar yang diberikan oleh

\footnotetext{
${ }^{16}$ Monte Palmer, Dilemas of Political Development Areas: An Introduction to Politics of Developing Areas, FE Peacock Publisher, Inc., Itasca, $3^{\text {rd }}$ Edition, Illinois, 1980, hlm. 3.

${ }^{17}$ Pasal 4 ayat (1) UU No. 25/2004 Tentang Perencanaan Pembanunan

${ }^{18}$ Rancangan Awal Rencana Pembangunan Jangka Menengah Nasional 2015-2019, Buku I, Kementerian Perencanaan Pembangunan Nasional , 2014, hlm 10
}

118 HUKMY|Jurnal Hukum 
umat Islam kepada Republik Indonesia. ${ }^{19}$

Konflik Islam dan politik muncul kembali ketika Orde Baru menerapkan kebijakan modernisasi, di mana stigma perkembangan pola pikir dan cara pandang bangsa Indonesia serta proses transformasi kultural dan perubahan sosial lebih banyak mengadopsi dari negara-negara Barat. Kiblat pembangunan Indonesia yang sebelumnya mengarah ke Eropa Timur berbalik arah ke Eropa Barat dan Amerika. Imbasnya, banyak kemudian terdapat kalangan cendekiawan dan intelektual mulai akrab dengan pemikiran-pemikiran Barat.

Sementara itu, bagi kalangan Islam, modernisasi ibarat dilema karena dihadapkan kepada dua pilihan, yakni apabila mendukung modernisasi ala Orde Baru yang berarti sama saja mendukung Barat, di sisi lain, apabila menolak berarti umat Islam akan kehilangan kesempatan untuk berperan aktif dalam pembangunan nasional. Dilema tersebut melahirkan tiga pola berikut: Pertama, pola apologi, yakni suatu bentuk sikap penolakan kalangan Islam terhadap segala nilai-nilai yang berakar pada wacana modernisasi. Bahkan pola pertama ini berasumsi bahwa modernisasi identik dengan westernisasi dan sekularisasi. Kedua, pola adaptif, yakni suatu bentuk sikap menerima sebagian nilai-nilai modernisasi yang tidak bertentangan dengan ajaran Islam. Ketiga, pola kreatif, yakni suatu bentuk sikap dialogis yang lebih mengutamakan pendekatan intelektual dalam menanggapi modernisasi. Dari ketiga pola tersebut, tampaknya pola ketiga menjadi lebih dominan karena pendekatan intelektual yang dikembangkan oleh kalangan modernis dipandang lebih representatif untuk membangun tatanan Islam modern di Indonesia. ${ }^{20}$

Pola pertautan politik yang serba provokatif dianggap bukan jalan terbaik bagi islamisasi di Indonesia, mengingat penduduk Indonesia tidak seluruhnya umat Islam yang dapat disatukan dalam bingkai sistem politik keormasan. Pada gilirannya, lahirlah gagasan Islam kultural sebagai jalan tengah bagi umat Islam untuk tetap memainkan perannya dalam pentas politik nasional. Paling tidak, kebenaran akan pendekatan ini mulai membuahkan hasil berupa terbukanya jalan bagi umat Islam

\footnotetext{
${ }^{19}$ Tujuh kata tersebut adalah "dengan menjalankan syari'at Islam bagi pemeluk-pemeluknya”. Mengenai piagam Jakarta lebih lanjut baca: Endang Saifuddin, Piaagam Jakarta 22 Juni 1945; Sebuah Konsensus Nasiional tentang Dasar Negara Republik Indonesia(1945-1949), cet. ke-1 (Jakarta: Gema Insani Press, 1997).

${ }^{20}$ M. Dawam Rahardjo, Intelektual, Intelegensia dan Perilaku PolitikBangsa (Bandung: Mizan, 1993), hlm. 381-382.
} 
menuju islamisasi politik Orde Baru di penghujung tahun $70-a n .^{21}$

Kebijakan-kebijakan politik Orde Baru yang menempatkan Islam dalam posisi marjinal di pentas politik nasional pada gilirannya telah melahirkan berbagai ketegangan antara Islam dan negara. Sejarah telah mencatat hahwa dinamika hubungan Islam dan negara pada masa Orde Baru mengalami pergeseran yang bersifat antagonistik, resiprokal kritis (timbal balik yang kritis) sampai akomodatif. Hubungan antagonistik (1966-1981) mencerminkan pola hubungan yang hegemonik antara Islam dengan pemerintah Orde Baru. Keadaan negara yang kuat memainkan pengaruh ideologi politik sampai ke tingkat masyarakat bawah telah berlawanan dengan sikap reaktif kalangan Islam sehingga melahirkan konflik ideologi dan sekaligus menempatkan Islam sebagai oposisi. ${ }^{22}$

Pada tahap hubungan resiprokal kritis (1982- 1985), kaum santri berupaya merefleksikan kembali cara pandang mereka dan merubah dirinya untuk menampilkan sisi intelektualitas dalam percaturan politik Indonesia. Pada tahap ini pilihan-pilihan rasional-pragmatis telah melahirkan saling pengertian akan kepentingan Islam dan pemerintah. Dalam kurun waktu 1982-1985 sebagian kalangan Islam mulai menerima asas tunggal sebagai landasan ideologi. ${ }^{23}$

Pada tahap hubungan akomodatif (1985-2000), hubungan Islam dan negara terasa lebih harmonis di mana umat Islam telah masuk sebagai bagian dan sistem politik elit dan birokrasi. Pola hubungan akomodatif ini sangat terasa berupa tersalurkannya aspirasi umat Islam untuk membangun tatanan sosial, politik, ekonomi dan budaya yang berakar pada nilai-nilai luhur Islam serta budaya bangsa yang dibingkai dalam falsafah integralistik Pancasila dan UUD $1945 .^{24}$

Namun demikian, khusus dalam sudut pandang perkembangan hukum Islam di Indonesia, kesempatan umat Islam untuk mendapatkan hak-haknya pada pola hubungan antagonistik lebih tampak. Posisi umat Islam yang begitu lemah, seperti ketika merumuskan UU No.1/1974, aliran kepercayaan dalam Pedoman Penghayatan dan Pengamalan Pancasila (P-4), isu ekstrim kanan, isu suku, agama dan ras (SARA),

\footnotetext{
${ }^{21}$ M. Syafi'i Anwar, Politik Akomodasi Negara dan Cendekiawan Muslim Orde Baru: Sebuah Retrospeksi dan Refleksi (Bandung: Mizan, 1995), hlm. 32-235.

${ }^{22}$ M. Syafi'i Anwar, Pemikiran dan Aksi Islam Indonesia; Sebuah Kajian Politik tentang Cendekiawan Muslim Orde Baru (Jakarta: Paramadina, 1995), hlm. 9.

${ }^{23}$ Ibid, hlm. 238-239.

${ }^{24}$ Ibid.
}

120 HUKMY|Jurnal Hukum 
isu kristenisasi dan kebijakan ekonomi kapitalistik. Protes umat Islam atas UU Perkawinan No.1/1974 yang disusul dengan PP No.9/1975, dianggap sebagai usaha Orde Baru untuk menggeser Hukum Islam dan akar tatanan sosial masyarakat Islam di Indonesia. ${ }^{25}$

Tersendat-sendatnya aspirasi umat Islam di dalam mendapatkan hak-hak perundang-undangan dan hukum tampak ketika dilegislasikannya UU No.1/1974 yang kemudian disusul dengan PP No.9/1975. Selanjutnya ditetapkan pula ketentuan tentang Wakaf dalam PP No.28/1977. Tidak berhenti sampai di situ, umat Islam di tingkat legislatif kembali mempersoalkan faham dan aliran kepercayaan dalam UUD 1945 sebagai agama resmi yang diakui negara. Dan yang paling krusial adalah kehendak umat Islam untuk dilegislasikannya Rancangan Undang-undang Peradilan Agama (RUU PA) bagi penyelenggaraan peradilan Islamdi Indonesia. ${ }^{26}$

Kemudian pada pola hubungan resiprokal kritis, umat Islam menyadari perlunya strategi untuk menempuh jalur struktural-birokrat pada sistem kenegaraan. Pada tahapan ini, kalangan cendekiawan dan politisi Islam harus berani bersentuhan langsung dengan pemerintahan Orde Baru. ${ }^{27}$ Melalui pendekatan strukturaifungsional, umat Islam relatif mengalami kemajuan pesat berupa masuknya kalangan Islam dalam segala sistem pemerintahan sipil mulai dari pusat hingga daerah, dan sekaligus memperkokoh kekuasaan Orde Baru dalam bingkai akumulasi sipil, Islam, dan militer.

Pada pola akomodatif, sebagai antitesa dan pola hubungan sebelumnya Islam hampir menguasai seluruh sendi-sendi pemerintahan dan negara. Tercatat realitas sosial politik umat Islam demikian penting memainkan peranannya di pentas nasional. Kehadiran ICMI, 8 Desember 1990, diyakini sebagai tonggak baru menguatnya islamisasi politik di Indonesia, dan semakin tampak ketika diakomodirnya kepentingan syari'at Islam melalui UUPA No.7/1989 sekaligus menempatkan Peradilan Agama sebagai lembaga peradilan negara yang diatur dalam UU Pokok Kekuasaan Kehakiman No.14/1970, disusul dengan UU Perbankan

\footnotetext{
${ }^{25}$ Hasanudin M. Saleh, HMI dan Rekayasa Asas Tunggal Pancasila (Yogyakarta: Pustaka Pelajar, 1996), hlm. 88-90.

${ }^{26}$ Ahmad Sukarja, "Keberlakuan Hukum Islam dalam Tata Hukum Indonesia" dalam Cik Hasan Bisri (ed.), Bunga Rampai Peradilan Islam di Indonesia, jilid I(Bandung: Ulul Albab Press, 1997), hlm. 24-25.

${ }^{27}$ M. Syafi'i Anwar, Pemikiran dan Aksi Islam di Indonesia, hlm. 241.
} 
No.10/1998 (pengganti UU No.7/1992), UU Zakat No.38/ 1999, KHI Inpres No.1/1991.28

Partisipasi politik kalangan umat Islam demikian tampak mulai dari pendekatan konflik, pendekatan resiprokal kritis sampai pendekatan akomodatif. Maka dapat diasumsikan untuk menjadikan Islam sebagai kakuatan politik hanya dapat ditempuh dengan dua cara yakni secara represif (konflik) dan akomodatif (struktural-fungsional). Paling tidak ini merupakan sebuah gambaran terhadap model paradigma hubungan antara Islam dan negara di Indonesia.

Untuk mengembangkan proses transformasi hukum Islam ke dalamsupremasi hukum nasional, diperlukan partisipasi semua pihak dan lembaga terkait, seperti halnya hubungan hukum Islam dengan badan kekuasaan negara yang mengacu kepada kebijakan politik hukum yang ditetapkan. Politik hukum tersebut merupakan produk interaksi kalangan elite politik yang berbasis kepada berbagai kelompok sosial budaya. Ketika elit politik Islam memiliki daya tawar yang kuat dalam interaksi politik itu, maka peluang bagi pengembangan hukum Islam untuk ditransformasikan semakin besar.

Sebagaimana negara berkembang lainnya, Indonesia selalu berusaha menjalankan pembangunan hukum nasional, yang meski dalam praktiknya sarat dengan nuansa dan pengaruh politik penguasa. Ketika berbicara mengenai pembangunan di bidang hukum, maka orientasinya adalah pada kodifikasi dan unifikasi hukum nasional. Sebagai upaya untuk mencapai produk hukum yang lebih responsif. Ketika kompetisi yang demokratis itu terjadi, maka usaha konsepsional menjadi bagian strategi tidak dapat diabaikan begitu saja, untuk menjadikan hukum Islam sebagai sumber hukum nasional, maka diperlukan sistem kerja positivisasi hukum Islam yang dapat diterima secara keilmuan dan melalui proses demokratisasi dan bukan indoktrinasi. ${ }^{29}$

Ketika berbicara mengenai positivisasi hukum Islam, maka sasarannya adalah menjadikan hukum Islam sebagai sumber pembuatan undang-undang, dalam pengertian yang lebih luas, termasuk di dalamnya keputusan hakim, kebiasaan, dan

\footnotetext{
${ }^{28}$ Cik Hasan Bisri, "Peradilan Agama dan Peradilan Islam”, dalam Cik Hasan Bisri (ed.), Bunga Rampai Peradilan Islam I, hlm. 116-117.

${ }^{29}$ A. Qodri Azizy, Eklektisisme Hukum Nasional, Kompetisi antara Hukum Islam dan Hukum Umum, cet. ke1 (Yogyakarta: Gama Media, 2002), hlm. 173.
} 
doktrin. Salah satu yang dihadapi bangsa Indonesia dalam mengembangkan sistem hukum nasional adalah pluralisme hukum, terutama antara hukum nasional dan hukum agama, khususnya hukum Islam sebagai bagian dari ajaran agama Islam yang dianut oleh mayorits warga negara Indonesia. Oleh karena itu, kedua sistem hukum tersebut harus diselaraskan, karena jika tidak, maka akan terjadi pertentangan dan konflik. ${ }^{30}$

Terhitung sejak tahun 1970-an sampai sekarang arah dinamika hukum Islam dan proses transformasi hukum Islam telah berjalan sinergis searah dengan dinamika politik di Indonesia. Tiga fase hubungan antara Islam dan negara pada masa Orde Baru yakni fase antagonistik yang bernuansa konflik, fase resiprokal kritis yang bernuansa strukturalisasi Islam, dan fase akomodatif yang bernuansa harmonisasi Islam dan negara, telah membuka pintu lebar bagi islamisasi pranata sosial, budaya, politik dan hukum Islam di Indonesia.

Dalam bentuk yang lebih kongkrit, terdapat beberapa produk peraturan dan perundang-undangan yang secara formil maupun material tegas memiliki muatan yuridis hukum Islam, antara lain: UU No.22/1946 Pencatatan Nikah, Talak, dan Rujuk, UU Darurat No.11/1957 tentang Susunan Kekuasaan dan Pengadilan Sipil, UU No.14/1970 tentang Kekuasaan Kehakiman, UU No.1/1974 tentang Hukum Perkawinan, UU No.7/ 1989 tentang Peradilan Agama (Kini UU No. 3/2006) , UU No.7/1992 tentang Perbankan Syari'ah (Kini UU No. 10/1998), UU No.17/1999 tentang Penyelenggaraan Ibadah Haji, UU No.38/ 1000 tentang Pangelolaan Zakat, Infak dan Shadaqah, UU No.4/1999 tentang Penyelenggaraan Otonomi Khusus Nangroe Aceh Darussalam, UU Politik 1999 yang mengatur ketentuan partai Islam,dan UU No.41/2004 tentang Wakaf.

Disamping tingkatannya yang berupa Undang-undang, juga terdapat peraturanperaturan lain yang berada di bawah Undang-undang, antara lain: PP. No.1/SD/1946 tentang membentuk Departemen Agama, PP No.9/1975 tentang Petunjuk Pelaksanaan UU Hukum Perkawinan, PP No.28/1977 tentang Perwakafan Tanah Milik, PP No.72/1992 tentang Penyelenggaraan Bank Berdasarkan Prinsip Bagi Hasil, Inpres No.1/ 1991 tentang Kompilasi Hukum Islam, dan Inpres No.4/2000 tentang

\footnotetext{
${ }^{30}$ Ibid.
} 
Penanganan Masalah Otonomi Khusus di Nangroe Aceh Darussalam.

Sejalan dengan perubahan iklim politik dan demokratisasi di awal tahun 1980an sampai sekarang, tampak isyarat positif bagi kemajuan pengembangan hukum Islam dalam seluruh dimensi kehidupan masyarakat. Pendekatan struktural dan harmoni dalam proses islamisasi pranata sosial, budaya, politik, ekonomi dan hukum, semakin membuka pintu lebar-lebar bagi upaya transformasi hukum Islam dalam sistem hukum nasional. Tinggal bagaimana posisi politik umat Islam tidak redup dan kehilangan arah, agar ia tetap eksis dan memainkan peran lebih besar dalam membesarkan dan kemajukan Indonesia baru yang adil dan sejahtera.

\section{Eksistensi Hukum Islam dalam Konfigurasi Politik Hukum Nasional di Masa yang} Akan Datang

Setelah 17 Agustus 1945, idealnya politik hukum yang berlaku adalah politik hukum nasional, artinya telah terjadi unifikasi hukum (berlakunya satu sistem hukum di seluruh wilayah Indonesia), karena sistem hukum nasional harus dibangun berdasarkan dan untuk memperkokoh sendi-sendi Proklamasi, Pancasila dan UUD 1945.31

UUD 1945 merupakan hukum dasar yang tertulis, disamping berlaku hukum dasar yang tidak tertulis-yang dijumpai di dalam penjelasan umumnya-menjadi dasar konstitusional dan sinyal organik keberadaan hukum tidak tertulis dalam tata hukum nasional. Norma dasar dalam Pasal II Aturan Peralihan UUD1945 menunjukkan isi awal tata hukum nasional dengan menyatakan segala peraturan yang ada masih langsung berlaku selama belum diadakan yang baru menurut UUD. Melalui konteks ini terlihat keadaan isi tata hukum nasional pada hari-hari awal kemerdekaan, yakni (1) hukum produk legeslatif kolonial, (2) hukum adat, (3) hukum Islam, dan (4) hukum produk legeslatif nasional. ${ }^{32}$

Sistem hukum nasional diharapkan dapat menjamin tegaknya supremasi hukum dan hak-hak asasi manusia berdasarkan keadilan dan kebenaran (sistem hukum modern). Sistem hukum yang modern haruslah merupakan hukum yang baik, dan sesuai dengan kondisi masyarakat. Hukum dibuat sesuai dengan prosedur yang

\footnotetext{
${ }^{31}$ Sunarjati Hartono, Mencari Bentuk dan sistem Hukum Perjanjian Nasional Kita, (Bandung: Alumni, Cet. 2, 1974), hlm 57.

${ }^{32}$ Ahmad Muliadi, Politik Hukum, Cet. I, (Padang: Akademika Permata, 2013), hlm. 47
} 
telah ditentukan, dan juga harus dimengerti atau dipahami oleh masyarakat secara keseluruhan, dengan tujuan supaya hukum benar-benar dapat mempengaruhiperilaku warga masyarakat. ${ }^{33}$ Sistem hukum nasional dibentuk dari :

a. Hukum Agama (yang dimasukkan adalah asas-asanya)

Sistem hukum agama adalah sistem hukum yang berdasarkan ketentuan agama tertentu, yang biasanya terdapat dalam Kitab Suci.

b. Hukum Adat ( yang dimasukkan adalah asas-asasnya)

Sistem hukum adat dan hukum kebiasaan adalah hukum asli masyarakat Indonesia, yang tumbuh dan berkembang dalam masyarakat Indonesia sejak ratusan bahkan ribuan tahun yang lalu. Penghormatan dan pengakuan terhadap masyarakat adat, termaktub dalam Pasal 18 B ayat (2) UUD 1945. Pasal ini merupakan mandat konstitusi yang harus ditaati oleh Penyelenggara Negara, untuk mengatur pengakuan dan penghormatan atas keberadaan masyarakat adat dalam suatu bentuk undang-undang.

c. Hukum Barat (yang dimasukkan adalah sistematikanya)

Sistem hukum perdata Eropa, yakni hukum perdata yang diberlakukan di Indonesia oleh Pemerintah kolonial berdasarkan asas konkordansi.

d. Hukum Internasional baik secara perdata maupun publik (sebagai bias relitas pengaruh globalisasi dunia). Hukum yang mengatur tentang hubungan hukum antara negara satu dengan negara lain atau antar warga negara yang dilakukan secara Internasional. ${ }^{34}$

Pembentukan hukum nasional dilaksanakan dengan mewujudkan perencanaan Prolegnas, ${ }^{35}$ dengan penyusunan daftar Rancangan UndangUndang, ${ }^{45}$ demikian dalam Prolegda juga menjaga agar produk Peraturan Daerah Provinsi tetap berada dalam kesatuan sistem hukum nasional. ${ }^{36}$

Tentang sistem hukum (legal system), menurut pendapat Lawrence M Priedmen sebagaimana dinukil oleh Ahmad Muliadi disebutkan bahwa dalam sistem hukum ada tiga unsur pokok dalam sistem hukum, yaitu : (1) unsur substansi hukum (legal substance), (2) unsur struktur hukum (legal struktur), (3)

\footnotetext{
${ }^{33}$ Ibid.

${ }^{34}$ Ibid, hal 54.

${ }^{35}$ Pasal 17 UU No. 12 Tahun 2011 tentang Pembentukan Peraturan Perundangundangan.

${ }^{36}$ Pasal 18 UU No. 12 Tahun 2011 tentang Pembentukan Peraturan Perundangundangan
} 
unsur budaya hukum masyarakat (legal culture).

Pentingnya pembahasan sistem hukum tersebut untuk menghimpun pemikiran-pemikmiran dari berbagai kalangan masyarakat mengenai program, metode, cara dan upaya pelaksanaan pembangunan hukum untuk menciptakan dan memantapkan sistem hukum nasional yang bersumber pada Pancasila dan UUD 1945. Sebagai suatu sistem hukum nasional, maka kebijakan pembentukan hukum nasional (perumusan pasal) harus dilakukan dengan melewati proses pengujian keabsahan hukumnya (termasuk substansi hukumnya) secara vertikal maupun horizontal. Hal ini dalam teori sistem hukum dikenal dengan "validitas vertikal " dan "validitas horizontal". ${ }^{37}$

Di Indonesia cara-cara yang digunakan untuk membentuk hukum, politik hukumnya tidak sama dengan cara-cara yan gidigunakan oleh Negara Kapitalis, atau Negara Komunis dan/atau Negara yang Fanatik Rerligius. Ketiga cara ini merupakan cara yang ekstrim; kaum Kapitalis menganggap bahwa manusia perorangan yang individualis adalah yang paling penting. Komunisme menganggap bahwa masyarakat yang terpenting di atas segalanya. Sedangkan Fanatik religius merupakan realitas bahwa manusia hidup di dunia ini harus bergulat untuk mempertahankan hidupnya (survive).

Sistem Pemerintahan Republik Indonbesia tidak terlepas dari pelaksanaan sistem-sistem di berbagai sektor lain yang mendukung roda pemerintahan, termasuk pula sistem hukum dan arah politik hukum dalam mencapai rencana dan tujuan bernegara yang berpalsafah Pancasila. ${ }^{38}$ Pancasila merupakan sumber segala sumber hukum Negara. ${ }^{39}$ Dalam membentuk Peraturan Perundangundangan harus dilakukan berdasarkan pada asas Pembentukan Peraturan Perundang-undangan yang baik, yang meliputi : a) kejelasan tujuan, b) kelembagaan atau pejabat pembentuk yang tepat; c) kesesuaian antara jenis, hierarki, dan materi muatan; d) dapat dilaksanakan; e) kedayagunaan dan kehasilgunaan; f) kejelasan rumusan; dan g) keterbukaan. ${ }^{40}$

Sedangkan materi muatan Peraturan perundang-undangan harus

\footnotetext{
${ }^{37}$ Ahmad Muliadi, Politik Hukum, hlm. 50

${ }^{38}$ Ibid, hal. 48.

${ }^{39} \mathrm{Ibid}, \mathrm{hlm} .50$

${ }^{40}$ Pasal 2 UU No. 12 Tahun 2011 tentang Pembentukan Peraturan Perundangundangan.
} 
mencerminkan asa-asas : a) pengayoman, b) kemanusiaan; c) kerbangsaan, d) kekeluargaan, e) kenusantaraan , f) bhinneka tunggal ika, g) keadilan, h) kesamaan kedudukan dalam hukum dan pemerintahan, i) ketertiban dan kepastian hukum, dan/atau j) keseimbangan, keserasian, dan keselarasan. ${ }^{41}$

Oleh karena itu apabila dalam pembentukan hukum nasional itu telah terakomodir asas-asas pembentukan hukum nasional sebagaimana disebutkan, dapat dimungkinkan hukum-hukum yang akan dibentuk itu akan dapat diberlakukan secara mulus sebagai kebutuhan hukum masyarakat, walaupun tetap adanya pro-kontra tanggapan masyarakat yang tidak seberapa, dan dapat dipastikan tidak akan terjadi pro-kontra tanggapan masyarakat yang berkepanjangan.

Adapun sistem hukum Pancasila dimaksudkan adalah seperangkat kaidah hukum dalam bebagai lapangan hukum yang merupakan bagian (unsur) daripadanya yang bersumber dasar pada Pancasila, yang satu sama lain berkait merupakan satu persatuan paduan hukum dalam satu wawasan nusantara wilayah Negara Republik Indonesia. ${ }^{42}$ Unsur-unsur sistem hukum Pancasila adalah kaidah- kaidah hukum dalam berbagai lapangan hukum (pidana, perdata, dagang, hukum acara, internasional dsb,) yang dirumuskan berdasarkan falsafah bangsa dan negara Pancasila. Karena sifatnya yang unik, maka sila pertama dari Pancasila, yaitu Ketuhanan Yang Maha Esa merupakan prima causa dari sila-sila lain dan merupakan sila dasar negara Republik Indonesia (Bab XI, Agama, pasal 29 ayat (1) UUD 1945) serta merupakan bagian integral dari keseluruhan sila menjadi satu kesatuan. Unsur-unsur tersebut berkait satu sama lain, merupakan satu kesatuan bulat, utuh, kompak, dan total sehingga merupakan satu kesatuan sistem yang kokoh. ${ }^{43}$

Apabila dikaitkan dengan kewenangan lembaga Yudikatif, di Indonesia hakim tetap terikat pada undang-undang, tetapi tidak seketat seperti aliran legisme. Hakim bertugas untuk menemukan hukum dan diberi kebebasan untuk menyelaraskan Undang-undang dengan perkembangan zaman. Pada aliran ini,

\footnotetext{
${ }^{41}$ Pasal 5 UU No. 12 Tahun 2011 tentang Pembentukan Peraturan Perundangundangan

42 Pasal 6 U U No. 12 Tahun 2011 tentang Pembentukan Peraturan Perudang -undangan.

${ }^{43}$ Ichtijanto, Sistem Hukum Pancasila, dalam Buku Hukum Islam di Indonesia Perkembangandan Pembentukannya, (PT. Rosdakarya, Bandung, Cet. I, 1991), hlm. 151.
} 
Yurisprudensi mempunyai kedudukan yang penting sebagai sumber hukum formil setelah undang-undang (dianut aliran rechtvinding plus). Dimaksudkan "Aliran rechtvinding plus" bahwa sangat dominan perilaku hakim dalam menemukan hukum untuk selalu menunjukkan etika dan tanggung jawab yang bukan saja bertanggung jawab untuk terwujudnya keadilan masyarakat, namun juga bertanggung jawab kepada Tuhan Yang Maha Esa. ${ }^{44}$

Sistem hukum Pancasila tidak dapat dan tidak mungkin meninggalkan hukum agama, karena hukum agama sebagai unsur dan asas-asas bahan baku pembentukan hukum nasional yang berfalsafah Pancasila, dapat bersama dengan hukum Adat dan hukum Barat. Namun, hukum Adat dan hukum Barat saja tanpa hukum agama akan menciptakan sistem hukum dan keadaan hukum seperti sewaktu rakyat Indonesia belum merdeka dan belum lahir negara Republik Indonesia yang berdasarkan Pancasila. Hukum Barat (terutama teknologi pengaturan perundang-undangan) sangat perlu dimanfaatkan untuk nuansa menciptakan hukum tertulis dalam upaya menjamin kepastian hukum dalam sistem hukum Pancasila. Pancasila mengakui adanya perbedaan agama dan mengakui serta menghormati perbedaan keyakainan. Namun Pancasila menghendaki persatuan dan kesatuan bangsa Indonesia. Oleh karena itu, dalam sistem hukum Pancasila musti ada norma yang berfungsi sebagai jembatan persatuan dalam hal ada perbedaan kepentingan hukum, karena perbedaan keyakinan, agama dan hukum agama. Kedamaian, kebahagiaan hidup, perlindungan hukum, jaminan hukum dan kepastian hukum dalam tertib hidup pribadi dan masyarakat, bangsa dan negara, kedamaian dunia adalah tujuan dan fungsi hukum dalam sistem hukum nasional yang berfalsafah Pancasila. ${ }^{45}$

\section{KESIMPULAN}

Perencanaan program pembangunan telah ditetapkan oleh MPR dalam GBHN, pada kenyataannya belum dapat terwujud secara sistemik. Evaluasi MPR sebelum menetapkan GBHN terakhir di masa transisi dari pemerintahan Orde Baru menuju era reformasi menyebutkan bahwa pembangunan selama pemerintahan era orde baru

\footnotetext{
${ }^{44}$ A. Qodri Azizi, Eklektisisme Hukum Nasional, Kompetisi antara Hukum Islam dan HukumUmum, hlm. 134

${ }^{45}$ Ichtijanto, Sistem Hukum Pancasila, hlm. 155 -156
}

128 HUKMY|Jurnal Hukum 
hanya terpusat pada sektor ekonomi tidak diimbangi dengan kemajuan pada sektor lainnya. Secara fisik terlihat kemajuan pada sektor ekonomi tapi secara fundamental rapuh karena tidak memiliki landasan hukum yang jelas, hukum jauh tertinggal. Konfiurasi politik di Indonesia perlahan namun pasti memberi ruang gerak yang cukup dinamis dalam mentransformasikan hukum Islam ke dalam sistem hukum nasional. Meskipun dalam roses dapat diklasifikasi ke dalam beberapa tahapan, terutama di masa rezim pemerintahan Orde baru, yaitu periode antagonistik, resiprokal dan persuasif.

Sikap akomodatif negara terhadap Islam lebih disebabkan oleh pemahaman negara terhadap perubahan sikap politik umat Islam terhadap kebijakan negara. Hal ini semakin menguat seiring bergulirnya era reformasi yang semakin mengakomodir eksistensi hukum Islam sebagai salah satu sumber pembangunan sistem hukum nasional Indonesia, selain hukum barat dan hukum adat. Sebagai landasan pembangunan hukum nasional, sudah sewajarnya hukum Islam mampu menawab berbagaipersoaalan-persoalan yang ada yang belum sepenuhnya mampu dipecahkan dengan menggunakan pendekatan sistem hukum peninalan kolonial. Sistem hukum Islam diangap lebih mencerminkan norma-norma kenusantaraan yan telah tumbuh dan mengakar kuat di dalam kehidupan masyarakat selama berabad-abad lamanya. Pembuktian ini tentu harus dilakukan secara bersama-sama oleh seluruh komponen bangsa, bukan saja bagi mereka yang beragama Islam, sebagai bagian yang integral dalam satu kesatuan sistem pembangunan hukum nasional sesuai dengan falsafah Pancasila serta UUD 1945.

\section{DAFTAR PUSTAKA}

Anwar, M. Syafi'i, Pemikiran dan Aksi Islam Indonesia; Sebuah Kajian Politik tentang CendekiawanMuslim Orde Baru Jakarta: Paramadina, 1995.

Politik Akomodasi Negara dan Cendekiawan Muslim Orde Baru: Sebuah Retrospeksidan Refleksi. Bandung: Mizan, 1995.

Azizy, A. Qodri, Eklektisisme Hukum Nasional, Kompetisi antara Hukum Islam dan Hukum Umum, cet. ke-1. Yogyakarta: Gama Media, 2002.

Bisri, Cik Hasan, "Peradilan Agama dan Peradilan Islam”, dalam Cik Hasan Bisri (ed.), Bunga RampaiPeradilan Islam I. 
Hartono, Sunarjati, Mencari Bentuk dan sistem Hukum Perjanjian Nasional Kita. Bandung: Alumni, Cet.2, 1974.

Harun, Refli, Kajian Politik Hukum terhadap Perencanaan Pembangunan Nasional Semesta Berencana Guna Meningkatkan Daya Bangsa, makalah disampaikan di Semarang tanggal, 28 Juli 2016.

Ichtijanto, Sistem Hukum Pancasila, dalam Buku Hukum Islam di Indonesia Perkembangandan Pembentukannya, PT. Rosdakarya: Bandung, Cet. I, 1991.

Mahfud, Moh. MD, Politik Hukum di Idonesia, Cet. 6. Jakarta: Raja Grafindo Persada, 2014.

Muliadi, Ahmad, Politik Hukum, Padang: Akademika Permata, Cet. I, 2013.

Mustofa dan Abdul Wahid, Hukum Islam Kontemporer, Jakarta: Sinar Grafika, 2009.

Najih, Mokhammad, Pengantar Hukum Indonesia, cet. 3 Malang: Setara Press, 2013.

Nasution, S., Metode Research (Penelitian Ilmiah), Cetakan ke-4, Jakarta: PT. Bumi Aksara, 2011.

Nonet, Philippe and Philip Selznick, Law and Transition: Towards Responsive Law, Harper \& Row, New York, 1978.

Palmer, Monte, Dilemas of Political Development Areas: An Introduction to Politics of Developing Areas, FE Peacock Publisher, Inc., Itasca, $3^{\text {rd }}$ Edition, Illinois, 1980.

Prayudi, RJPN Tahun 2005-2025 Sebagai Landasan Pembanguan Politik Memperkuat Demokrasi, JurnalKonstitusi, Volume 4, Nomor 3, September 2007.

Rahardjo, M. Dawam, Intelektual, Intelegensia dan Perilaku PolitikBangsa. Bandung: Mizan, 1993.

Rancangan Awal Rencana Pembangunan Jangka Menengah Nasional 2015-2019, Buku I, KementerianPerencanaan Pembangunan Nasional.

Saifuddin, Endang, Piaagam Jakarta 22 Juni 1945; Sebuah Konsensus Nasional tentang Dasar Negara Republik Indonesia (1945-1949), cet. ke-1. Jakarta: Gema Insani Press, 1997.

Saleh, Hasanudin M., HMI dan Rekayasa Asas Tunggal Pancasila. Yogyakarta: Pustaka Pelajar, 1996

Saragih, Bintan Regen, Politik Hukum, Bandung: CV. Utomo, 2006

Sidharta, Arief, Hukum dan Logika, Bandung: Alumni, 2006.

Sirajuddin, M., Legislasi Hukum Islam di Indonesia, Yogyakarta: Pustaka Pelajar,2008.

Sukarja, Ahmad, "Keberlakuan Hukum Islam dalam Tata Hukum Indonesia" dalam Cik Hasan Bisri (ed.), Bunga Rampai Peradilan Islam di Indonesia, jilid I. Bandung: Ulul Albab Press, 1997.

130 HUKMY|Jurnal Hukum 
Volume 1, No. 1, April 2021

Undang-Undang Nomor 12 Tahun 2011 tentang Pembentukan Peraturan Perundangundangan.

Undang-Undang Nomor 12 Tahun 2011 tentang Pembentukan Peraturan Perundangundangan.

Undang-Undang Nomor 12 Tahun 2011 tentang Pembentukan Peraturan Perudang undangan.

Undang-Undang Nomor 25/2004 Tentang Perencanaan Pembanunan 